\title{
KORAI INTERVENCIÓ EGY KUTATÁS TÜKRÉBEN
}

\author{
Szerzők: \\ Laoues-Czimbalmos Nóra \\ Debreceni Egyetem (Magyarország) \\ Mercsné Konyári Anita \\ Hajdúsámson, Eszterlánc Óvoda (Magyarország) \\ Bíró Melinda (Ph.D.) \\ Debreceni Egyetem (Magyarország) \\ Müller Anetta (Ph.D.) \\ Debreceni Egyetem (Magyarország)
}

\author{
Lektorok: \\ Váczi Péter (Ph.D.) \\ Eszterházy Károly Egyetem (Magyarország) \\ Bocsi Veronika (Ph.D.) \\ Debreceni Egyetem (Magyarország) \\ ...és további két anonim lektor
}

Első szerző e-mail címe:

laoues.nora@ped.unideb.hu

Laoues-Czimbalmos N., Mercsné Konyári A., Bíró M., Müller A. (2020). Korai intervenció egy kutatás tükrében. Különleges Bánásmód, 6. (3). 17-32. DOI 10.18458/KB.2020.3.17

\begin{abstract}
Absztrakt
Napjainkban egyre növekszik a sajátos nevelési igényú (SNI) gyermekek száma, melyek új kihívásokat jelentenek a szülőknek és pedagógusoknak egyaránt. Fontos tehát ennek a tématerületnek a kutatása a szülook és a szakemberek oldaláról vizsgálva. 2019 év elején Hajdú-Bihar és Szabolcs-Szatmár-Bereg megyében kérdőíves kutatást végeztünk a korai intervenció témakörben. Az online és papír alapú kérdôíveket szülők ( $N=103)$ és szakemberek ( $N=106)$ (óvodapedagógus, gyógypedagógus, konduktor, stb), összesen 209 kérdőívet dolgoztunk fel. Az adatgyüjtés név nélkül történt és a részvétel önkéntes volt. A kérdőívben lévő adatok feldolgozása után Excel táblázat segítségével és SPSS 21.0 statisztikai programmal elemeztük a kapott eredményeket. Az eredmények azt mutatják, hogy mind a szülők (76,7\%), mind a szakemberek (71,7\%) úgy vélik, hogy az SNI gyermekek fejlődését teljes mértékben vagy nagyon befolyásolta az integrálás, azaz pozitívan értékelték. Az ép gyermekek szülei elfogadják az integrációt, a különböző színtereken ( a válaszadók óvodában 43,7\%-a, az iskolában 37,9\%-a, a játszótéren 67\%-a teljes mértékben elfogadja az ép gyermekével együtt jár sajátos nevelési igényú gyermek is).
\end{abstract}

Kulcsszavak: sajátos nevelési igényú, korai intervenció, fejlődés, integráció

Diszciplinák: szociológia, pedagógia 


\section{Abstract \\ EARLY INTERVENTION IN THE LIGHT OF A RESEARCH}

Nowadays, the number of children with special educational needs (SEN) is increasing, which poses new challenges for both parents and educators. It is therefore important to research this topic from the perspective of parents and professionals. At the beginning of 2019, we conducted a questionnaire survey on early intervention in Hajdú-Bihar and Szabolcs-Szatmár-Bereg counties. The online and paper-based questionnaires were processed by parents $(N=103)$ and professionals $(N=106)$ (kindergarten teacher, special education teacher, conductor, etc.), for a total of 209 questionnaires. Data collection was anonymous and participation was voluntary. After processing the data in the questionnaire, we analyzed the obtained results using an Excel spreadsheet and a SPSS statistical program. The results show that both parents $(76,7 \%)$ and professionals $(71.7 \%)$ believe that the development of children with SNI was fully or strongly influenced by integration, i.e., they were positively assessed. Parents of healthy children accept integration, in different settings (43.7\% of respondents in kindergarten, $37.9 \%$ in school, $67 \%$ in the playground) fully accept children with special educational needs who accompany their intact child.).

Keywords: special educational needs, early intervention, development, integration

Disciplines: sociology, pedagogy

A gyermekek fejlődése a korai életévekben a leggyorsabb, ám a gyermekek sérülékenysége is ilyenkor a legfokozottabb. A téma jelentőségénél fogva igen széles azoknak a szakirodalmaknak a háttere, melyek a korai életkori szakasz vagy az óvodások célcsoportjára fókuszál (Kereki és Szvatkó, 2015, Kiss, 2019, Márkus és Fülöp, 2017, Jenei, 2012, Andrásné, 2010). Az örökléssel kapcsolatos vizsgálatok arra keresik a választ, hogy a genetikai állomány mennyiben determinálja az embert, azon belül is külön szakirodalmi háttér foglalkozik a mozgás és a mozgásos teljesítmény öröklött oldalával (Völgyesi, 1993, Mészáros és tsai 1990, Farmosi, 1999).

A mozgásfejlődés és fejlesztés ezért a korai életszakaszban igen fontos, hiszen az értelmi fejlődést is determinálja. Illetve a korai életkori szakaszban végzett prevenciós tevékenységekre irányuló figyelem több szempontból is fontos. Amennyiben ezt az időszakot nem használják ki a szakemberek, szülők akkor a gyermekek valószínúleg nem jutnak el arra a szintre, ami a benne lévő készségek lehetôvé tennének. A korai intervenció hatására a gyermekek könnyebben le tudják küzdeni hátrányaikat, ennek hatására aktívabb és sikeresebb, minőségileg jobb életet tudnak élni. A gyermekek egyéni fejlődésének támogatásán túl fontos a család helyzetének stabilitása, mivel a család funkciója többrétú, ellátja a gyermek gondozását, biztosítja azokat a feltételeket, amelyek a gyermek fejlődéséhez szükségesek (Laoues, 2017).

Több hazai kutatás (Bakonyi és Nádori, 1979, Ákoshegyiné, 1986, Farmosi és Gaál, 2007, Eigner, 2012) megerősíti, hogy a kedvezőtlen szocioökonómiai háttérrel rendelkező, vagyis szociálisan elhanyagolt gyermekek motorikus teljesítménye és mozgásának fejlődése is elmarad azokétól a gyerekekétől, akik rendezett családban élnek, kedvező szocioökonómiai státusszal rendelkeznek. A család, mint elsődleges szocializációs színtér szerepe tehát a gyermek értelmi, érzelmi és motorikus fejlődésében is meghatározó (Farmosi és Gaál, 2001) . A korai intervenció a családokat is támogatja, ami hozzájárul a gyermekük jelentős fejlődéséhez. En- 
nek hatására a szülők megfelelő segítséget tudnak nyújtani a gyermekük fejlődéséhez, tanulásához, megismerik fejleszthetőségüket, jogaikat, így jobban tudják képviselni a gyermekük érdekeit. A szülők segítséggel, támogatással könnyebben el tudják fogadni gyermeküket. A szakemberek munkája hozzásegíti a gyermekeket, a minél sikeresebb beilleszkedésüket a társadalomba. Az integráció minden olyan gyermeket érint, akinek valami folytán nehézségei vannak (Mező és tsai, 2015).

A sajátos nevelési igényü gyermek fejlesztésének legfontosabb tényezője a család. Ugyanakkor a fejlesztésben meghatározó a család külső kapcsolatrendszere is, a gyermekkel foglalkozó szakemberek (orvos, gyógypedagógus, pszichológus stb.). A segítő szakember egyfelől megerősíti a családoknak azt a képességét, amely képessé teszi őket arra, hogy megbirkózzanak a problémákkal, másfelől a környezet minőségét tökéletesíti (Budai, 1996).

\section{Irodalmi áttekintés}

A témával foglalkozó hazai szakemberek egyetértenek a korai intervenció fogalmának bevezetésével, illetve gyakorlati használatával. Hangsúlyozzák, hogy nem a korai terápiával egyenlő tevékenység, bár a különböző terápiák szerves részét képezik a tevékenységnek. (Rosta, 2006). A korai intervenció értelmezésére a nyugat-európai országokban már a hatvanas évektől törekedtek. Bevezették a „korai terápiall elnevezést. Felismerték, hogy nem csupán a kisgyermekek terápiás megsegítése a cél, hanem azt is, hogy a család és annak környezetével való szoros együttmúködés és felvilágosító munka nélkül nincs megfelelő hatékonyság (Rosta, 2006; Kereki, 2010).

$\mathrm{Az}$ egészség megőrzésének leghatékonyabb eszköze a megelőzése. Czeizel (2009) meghatározása szerint a korai fejlesztés Magyarországon az 1990-es évek elejére tehetó, amikor a gyógypedagógián belül egy önálló tudományággá vált. Korábban használatos és elterjedt kifejezés a korai fejlesztés volt, ez mára már átalakult és a koragyerekkori intervenció fogalmát használják helyette.

A gyógypedagógusok többnyire még a korai fejlesztést, míg az egészségügy inkább a korai intervenciót használja (Kereki és Lannert, 2009). A korai fejlesztés nevéből adódik, hogy ez a legkorábban nyújtható szakszolgálati forma, amely egyben különleges gondozáshoz való jogot is jelent. Czeizel (2009) a gyermeklélektani kutatások által feltárt magyarázattal érvel, miszerint az ember fejlődése az élet első éveiben a legszembetúnőbb ütemú. Ha ezt az időszakot nem használják ki megfelelően a nem normál ütemben fejlődő gyermekeknél, akkor a gyermek bizonyos képességeket soha sem, vagy csak nehezen fog megszerezni. Kereki (2013) az intézményrendszer együttmúködésének fontosságára utal. „A gyermeki fejlődés üteme az első években a leggyorsabb, a mozgásos, kognitív, nyelvi funkciók kiépülése, a szociális, önszabályozó képesség kialakulása, az érzelmi biztonság, fizikai egészség megalapozása ebben az időszakban zajlik, és jelentősen befolyásolja a későbbi életlehetőségeket. Nem mindegy, hogy a gyermeket és családot körülvevő ellátó rendszerben felismerik-e, illetve mikor ismerik fel és azonositják a problémákat, segítik-e a szülót a felismerésben, eljutnak-e a szükséges információk az érintettekhez, biztosítja-e a rendszer a szolgáltatásokhoz való hozzáférést, az idôben való ellátásba kerülést, garantálja-e a megfelelő színvonalú ellátást" (Kereki, 2013.23.).

A korai fejlesztés a gyermek fejlődésére irányult, míg a koragyermekkori intervenció a gyermeket, a családot és a környezetét is figyelembe veszi. A koragyerekkori intervenció magába foglalja a preilletve a perikoncepcionális idôszak preventív jellegủ szolgáltatásait (gyermekekre és a családjaikra irányuló ellátások, szolgáltatások) és a fogantatástól a gyermek iskolába lépéséig (Kereki, 2017). A szűrővizsgálat során megállapított diagnózist követően a gyermeknek fejlesztési lehetőségeket java- 
solnak, a család megsegitésére tanácsokkal és a jutatások rendszerét kínálják fel számukra. A koragyermekkori intervenciós idôszak a fogantatástól az iskolakezdésig tart. A korai gyerekkorban zajló folyamatok későbbi életszakaszban van nagy hatással. Az időben nyújtott prevenciós és intervenciós szolgáltatásoknak köszönhetően a gyermekek életminősége javulhat.

A gyermekek fejlesztésére, mára már rengeteg lehetőség és eljárás létezik. Azonban bizonyos terápiáknál figyelembe kell venni a gyermekek korát és állapotát. Fontos megtalálni a számára legeredményesebb eljárást a megfelelő fejlődés érdekében. A kezelési eljárásokat a mindennapokba be kell építeni, még akkor is, ha a javulás hosszú idó alatt lesz észlelhetô. A szülők és a gyermekek számára sem könnyú feladat, de a kitartó, sokszor embert nem kímélő munkának meg lesz a kedvező hatása.

A sajátos nevelési igényú gyermekek fejlesztő terápiái közzé számos lehetőségek változata ismert jótékony hatásairól, ilyen pl.:

- Ayres-terápia: szenzoros integrációs terápia. A magatartás és tanulásizavarokkal küzdô gyermekek kezelésére szolgál (Csirkés és tsai 2015).

- Doman-Delecato-módszer: idegrendszer működésének fejlesztésére szolgál. Az autista gyerekeknek ajánlják.

- Alapozó terápia: a gyermekeknek végig kell menni a fejlődés minden szakaszán ahhoz hogy a kommunikáció fejlődése ne sérüljön. Ha a fejlődésnél kimarad valamilyen mozgás pl: kúszás, mászás, stb. probléma/ mozgás,beszéd-, írásbeli hiányosság/ alakulhat ki a gyermekek fejlődésénél. A terápiával beindítható az idegrendszer érési folyamata így a hiányosságok javulnak.

- TSMT-módszer: Tervezett Szenzomotoros Tréningek: a vesztibuláris rendszer ingerlésével fejlesztik a gyermekeket. Különböző forgásokkal, pörgésekkel zajlik a terápia. Lehet csoportos és egyéni foglalkozás. Epilepsziás gyerekeknek nem ajánlott ezt a terápiát végezniük, mert rohamot idézhet elő bizonyos mozdulatsor alkalmazása.

Ezek a terápiák a legismertebbek Magyarországon, de vannak még terápiás eljárások ilyen a INPP-program, Sindelar-terápia, Frostig-terápia, labdaterápia, különböző állat terápia/lovas, kutyás terápia/ zene terápia (Kereki, 2017).

\section{Módszer}

A kutatást két megyéjében (Hajdú-Bihar és Szabolcs-Szatmár-Bereg megyében) 2019 februárjában végeztük. A vizsgálathoz két kérdőívet is készítettünk. Megkerestük a helyi óvodában a szülóket, az intézményben dolgozó óvodapedagógusokat, fejlesztôpedagógusokat és gyógypedagógust, illetve a környező intézményben dolgozó szakembereket. Kutatásunkhoz olyan óvodát is választottunk, ahol már több éve integrálnak sajátos nevelési igényű gyermekeket. A kérdőív kitöltői szülők és szakemberek (óvodapedagógus, gyógypedagógus, konduktor, stb) voltak. A vizsgálatban papíralapú, valamint online kérdôívezést alkalmaztunk. A kérdôíveket 209 fő töltötte ki, ebből 103 fó szülő és 106 fő szakember járult hozzá a kérdőívek kitöltéséhez. Az adatgyújtés név nélkül történt és a részvétel önkéntes volt. A kérdőívben lévő adatok feldolgozása után Excel táblázat segítségével és SPSS 21.0 statisztikai programmal elemeztük a kapott eredményeket.

A kutatás során célunk, hogy a szülőkkel és a szakemberekkel végzett kérdőív-attitűdvizsgálatsegítségével feltárjuk, hogy mennyire informáltak a szülők, az óvodapedagógusok és a szakemberek a sajátos nevelési igényű gyermekek integrációjával és a fejlesztésekkel kapcsolatosan, illetve a szülők és a szakemberek elfogadják és támogatják a sajátos nevelési igényú gyermekek integrációját.

Tapasztalataink alapján feltételezzük, hogy ha a szülők problémát észlelnek gyermekük fejlődése 
során nem tudják kihez forduljanak, nem ismerik a pedagógiai szakszolgálatot, nem kapnak (vagy megkésve kapnak csak) elég információt a megfelelő fejlődés menetérôl és a fejleszthetôségekről. Az elképzeléseink szerint a sajátos nevelési igényú gyermeket integráló óvodák óvodapedagógusai úgy vélik, több szakmai, gyógypedagógiai segítségre lenne szükségük az integráció teljes megvalósulásához.

A tanulmányunkban az alábbiakra kerestük a választ:

- Befolyásolja-e a sajátos nevelési igényú gyermek fejlődését az integrálás?

- Az ép gyermekek szülei elfogadják -e az óvodában, az iskolában és a játszótéren, hogy gyermekikkel együtt nevelkednek és játszanak sajátos nevelési igényűek is?

- A szakemberek az integrálást jó lehetőségnek tartják-e a sajátos nevelési igényú gyermekek számára?

- A szakemberek tisztában vannak-e a korai fejlesztés igénybevételének módjával?

- A szülők többsége kapott-e tájékoztatást gyermekük fejlődési szakaszairól?

\section{Minta}

A válaszadó szülők 103 fó, a szakemberek közül 106 fő volt. A válaszadó szülők megoszlása szerint 54,4\%-nak gyermekük óvodába jár és 45,6\%-nak bölcsődébe jár a gyermekük. A szakemberek megoszlása szerint 38,7\%-a óvodapedagógus, 39,6\%-uk gyógypedagógus, 13,2\%-a fejlesztőpedagógus, 5,7\%-uk gyógytestnevelő tanár és 2,8\%-a konduktor volt. Az 1. ábra szemlélteti a válaszadó szakemberek munkaterületének megoszlását.

1.ábra. A szakemberek válaszainak megoszlása (Forrás: a Szerzőók)

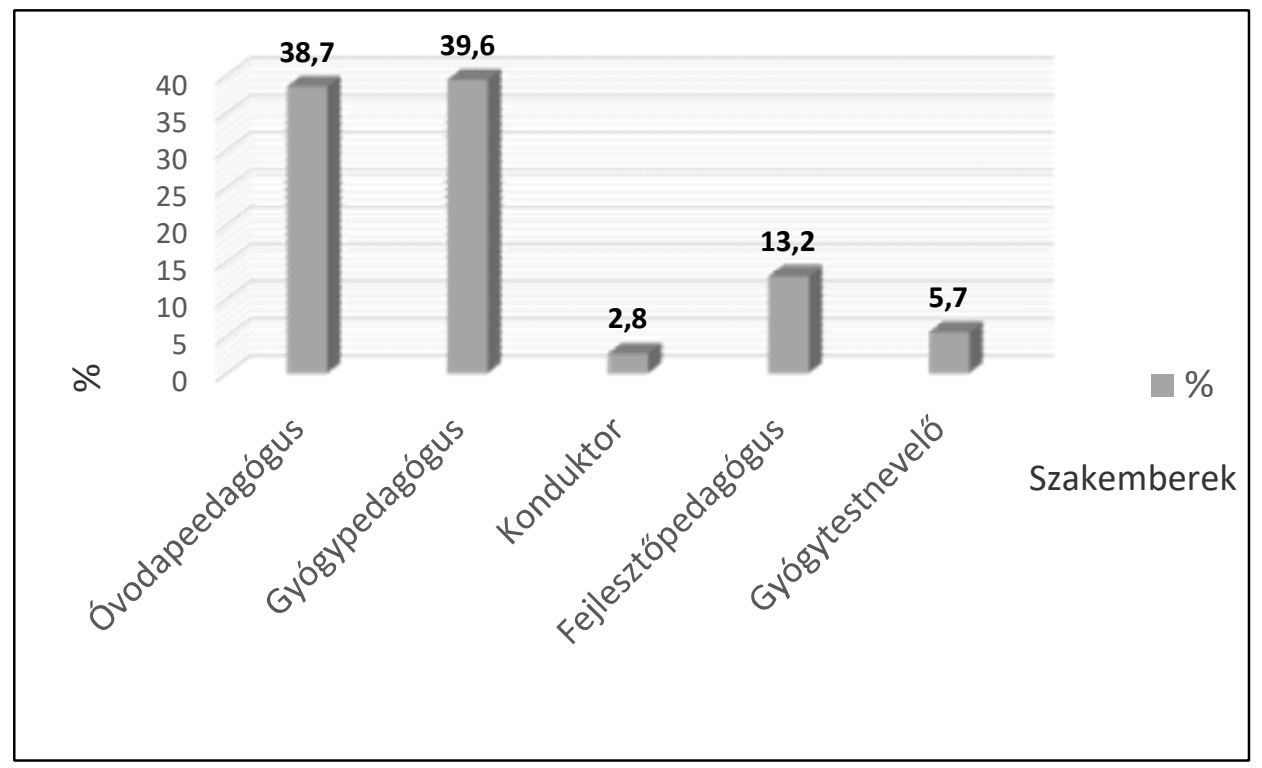




\section{Eszközök}

A kitöltők Hajdú-Bihar és Szabolcs-Szatmár Bereg megyében élő szülők és szakemberek vettek részt a kutatásban. A vizsgálatban papíralapú, valamint online kérdőívezést alkalmaztunk.

A kérdőíveket 209 fö töltötte ki, ebből 103 fó szülő és 106 fő szakember járult hozzá a kérdőívek kitöltéséhez. Az adatgyújtés név nélkül történt és a részvétel önkéntes volt. A kérdőívben lévő adatok feldolgozása után Excel táblázat segítségével és SPSS 21.0 statisztikai programmal elemeztük a kapott eredményeket.

\section{Eredmények}

A minta nemek és életkori megoszlása

A válaszadó szülók közül férfi 19,4\%-a, nő 80,6\%-a. A válaszadó szakemberek közül férfi 11,3\%-a, nő 88,7\%-a töltötte ki a kérdôívet. A válaszadók életkori megoszlása szerint a szülők 36,9\%a 25-35 év közötti, 56,3\%-a 35-45 év közötti illetve 6,8\%-a 45év feletti. A válaszadó szakemberek életkori megoszlása szerint 23,6\%-a 25-35 év közötti, 38,7\%-a 35-45 év közötti, 37,7\%-a 45 év feletti volt. A minta nemek és életkori megoszlását részletesen az 1. táblázat szemlélteti.

1. táblázat: A válaszadók nemek és életkori megoszlását (Forrás: a Szerzoỏk)

\begin{tabular}{|l|c|c|c|c|c|c|}
\hline $\begin{array}{c}\text { A válaszadók } \\
\text { adatai }\end{array}$ & \multicolumn{3}{|c|}{ Szülők } & \multicolumn{3}{c|}{ Szakemberek } \\
\hline \multirow{2}{*}{ Életkor (\%) } & $25-35$ év & $35-45$ év & $\begin{array}{c}45 \text { év } \\
\text { felett }\end{array}$ & $\begin{array}{c}25-35 \\
\text { év }\end{array}$ & $35-45$ év & $\begin{array}{c}45 \text { év } \\
\text { felett }\end{array}$ \\
\cline { 2 - 7 } & $36,9 \%$ & $56,3 \%$ & $6,8 \%$ & $23,6 \%$ & $38,7 \%$ & $37,7 \%$ \\
\hline Nem & \multicolumn{3}{|c|}{$19,4 \%$} & \multicolumn{3}{c|}{$11,3 \%$} \\
\hline Férfi (\%) & $80,6 \%$ & $88,7 \%$ \\
\hline Nő (\%) & \multicolumn{3}{c|}{} \\
\hline
\end{tabular}

\section{A minta településtipusonkénti megoszlása}

A válaszadók többsége városban lakik, azaz szülők közül 71,8\%-a lakik városban és 28,2\%-a faluban/községben. A szakemberek közül 62,3\%-a lakik városban és 37,8\%-a faluban /községben. A válaszadók településtípusonkénti bontását a 2 . ábra szemlélteti.

\section{Továbbképrésekkel kapcsolatos vélemények}

A válaszadó szakemberek közül 59,4\%-a vett részt valamilyen (gyógypedagógiai tanácsadás, korai fejlesztés) oktatás és gondozás területének megismerésén, 40,6\%-a nem vett részt továbbképzésen.
A válaszadó szakemberek közül a többség 60,4\%-a szívesen részt venne SNI témakörében szervezett továbbképzésen, 24,5\%-a nagyobb mértékben igen, 8,5\%-a kismértékben, 2,8\%-a nem és $0 \%$-a egyáltalán nem venne részt továbbképzésen (3. ábra).

\section{A korai fejlesztés kezdetére vonatkozó ismeretek}

A válaszadó szakemberek közül a többség 80,2 \%-a tisztában van a korai fejlesztés igénybevételének módjával, a $19.8 \%$-a viszont nincs tisztában. A válaszadók magoszlását az 4 . ábra szemlélteti. A korai fejlesztés igénybevételénél nagyon fontos, hogy a szülő tájékozott-e a lehetőségekről. Tudja-e 
2.ábra: A válaszadók településtípusonkénti megoszlása (Forrás: a Szerzőke)

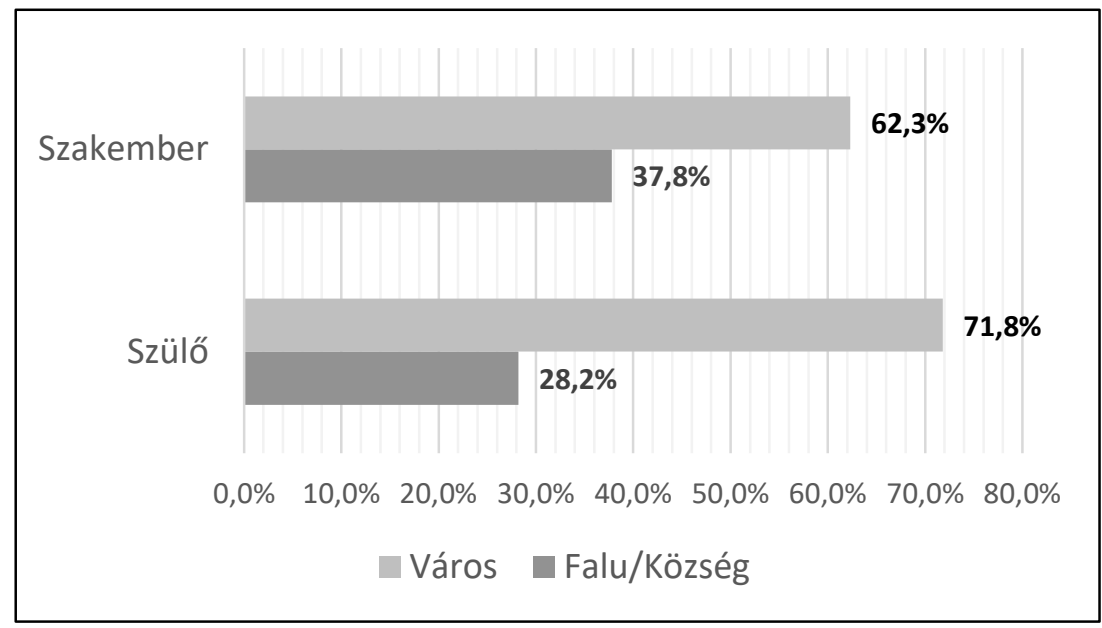

3. ábra: A válaszadó szakemberek továbbképzésének megoszlása (Forrás: a Szurzőe)

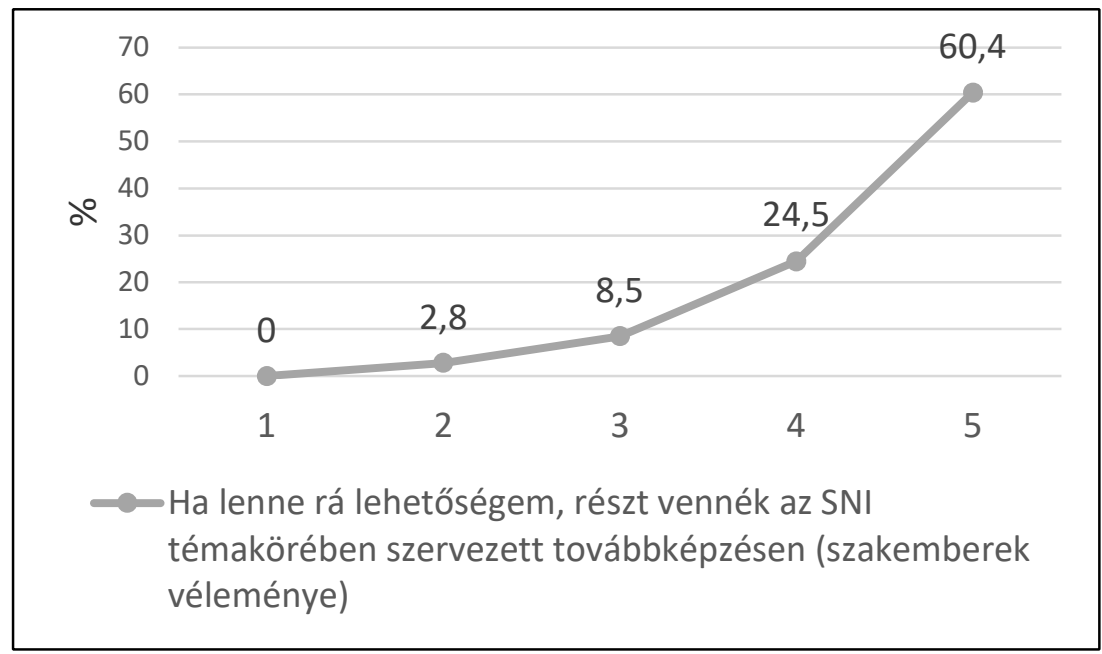

*1-es egyáltalán nem jellemző, 5-ös teljes mértékben jellemző

a szülő, hogy a gyermekének a fejlődési szakasza a megfelelő ütemben fejlődik-e, erről kaptak-e tájékoztatást? Erre a kérdésre a szülők többsége 64,1\%-a igennel válaszolt, 14,6\%-a nem, 20,4\%-a nem emlékszik és 1\%-a nem válaszolt.

\section{A válaszadók véleményei a fejlesztési lehetöségekeról}

A válaszadó szülők és a szakemberek lakóhelyükön vagy a településhez közel van korai fejlesztés vagy egyéb pedagógiai szakszolgálat. A szülők válaszai alapján 32\%-a válaszolta azt, hogy nincs a településen ahol élnek, de a közelben van, 26,2\%-a van a településen, 17,5\%-a nem tudja, 16,5\%-a válaszolta, hogy nincs és 7,8\%-a, hogy még nem hallott a korai fejlesztés lehetőségéről.

A szakemberek közül 69,8\%-a válaszolta, hogy van, ahol él korai fejlesztés vagy egyéb pedagógiai szakszolgálat, 15,1\%-a azt válaszolta, hogy nincs, 
KÜLÖNLEGES BÁNÁSMÓD, VI. ÉVF. 2020/3.

4. ábra: A válaszadók (szakemberek) a korai fejlesztés igénybevételének ismereteinek megoszlása (Forrás: a Szerzőo.k)

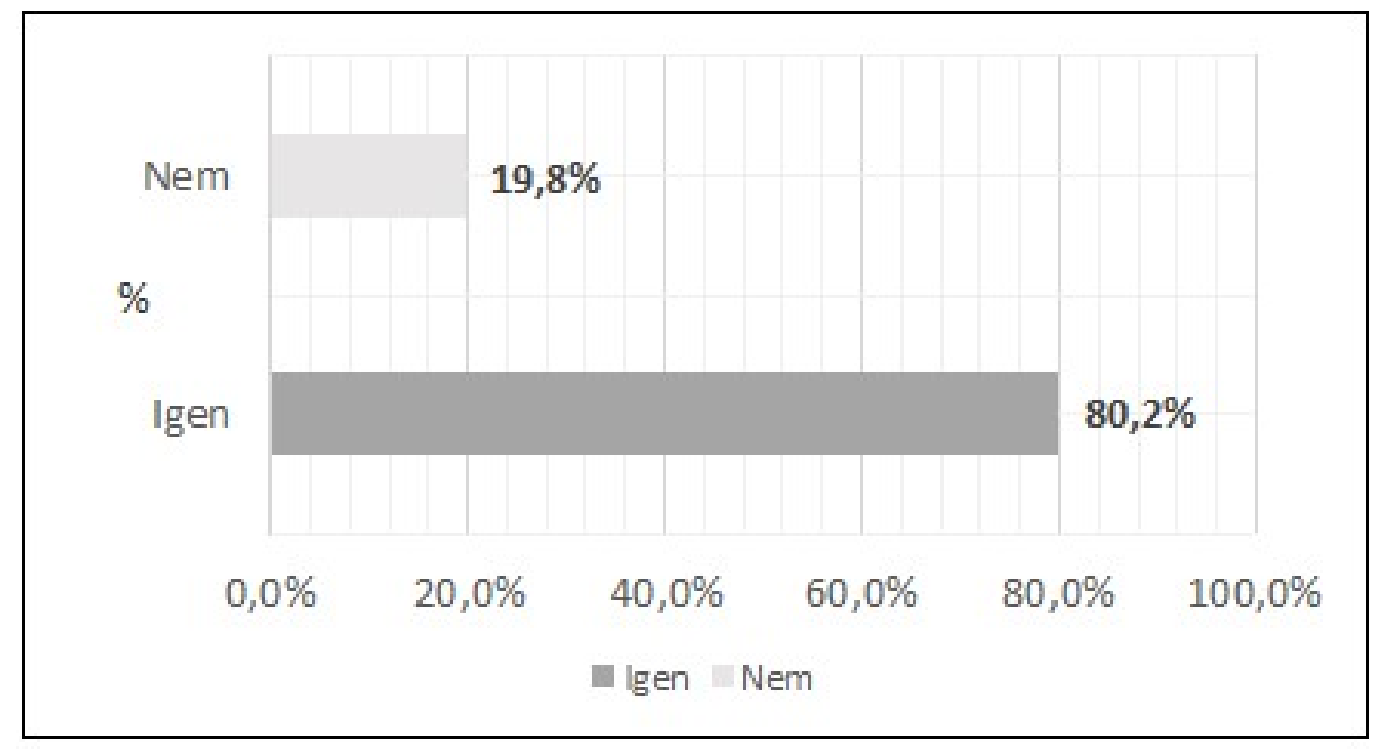

5. ábra: A válaszadók tájékozottsága a korai fejlesz̧tés helyének aranyának megoszlása (Forrás: a Szerzók).

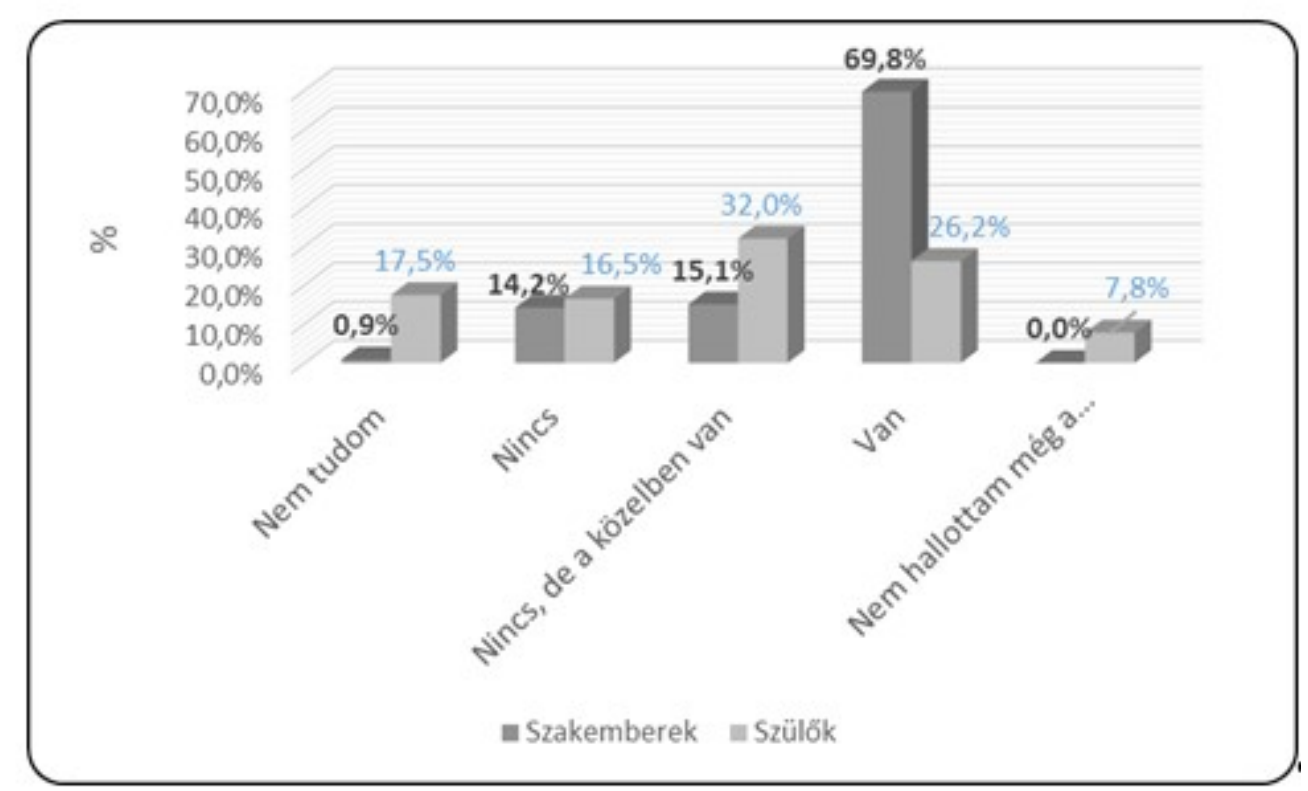

de a közelben van, 14,2\%-a szerint nincs, 0,9\%-a nem tudja és $0 \%$-a az aki még nem hallott róla. Az 5. ábra szemlélteti a válaszadók tájékozottságát a korai fejlesztés vagy a pedagógiai szakszolgálat helyének megoszlását. 


\section{A szülök tájékozottsága a fejlesztési lehetöségekröl}

A szakemberek tapasztalatai szerint a szülők 43,4\%-a talán igen, talán nincs tisztában a fejleszthetőségekkel, illetve 25,5\%-a egyáltalán nincs tisztában, 25,5\%-a nincs tisztában, 5,7\%-a igen, tisztában van a lehetőségekkel és $0 \%$-a aki a szakemberek szerint teljes mértékben tisztában van. A 6. ábra szemlélteti, hogy a szakemberek szerint a szülők nagy többsége nincs tisztában a gyermekeik számára a fejleszthetőségekkel.

6. ábra: A szakemberek tapasz̨talatai szerint a szülök tájékozottsága a gyermekeik fejleszthetöségének arányának megoszlása (Forrás: a Szerzőo)

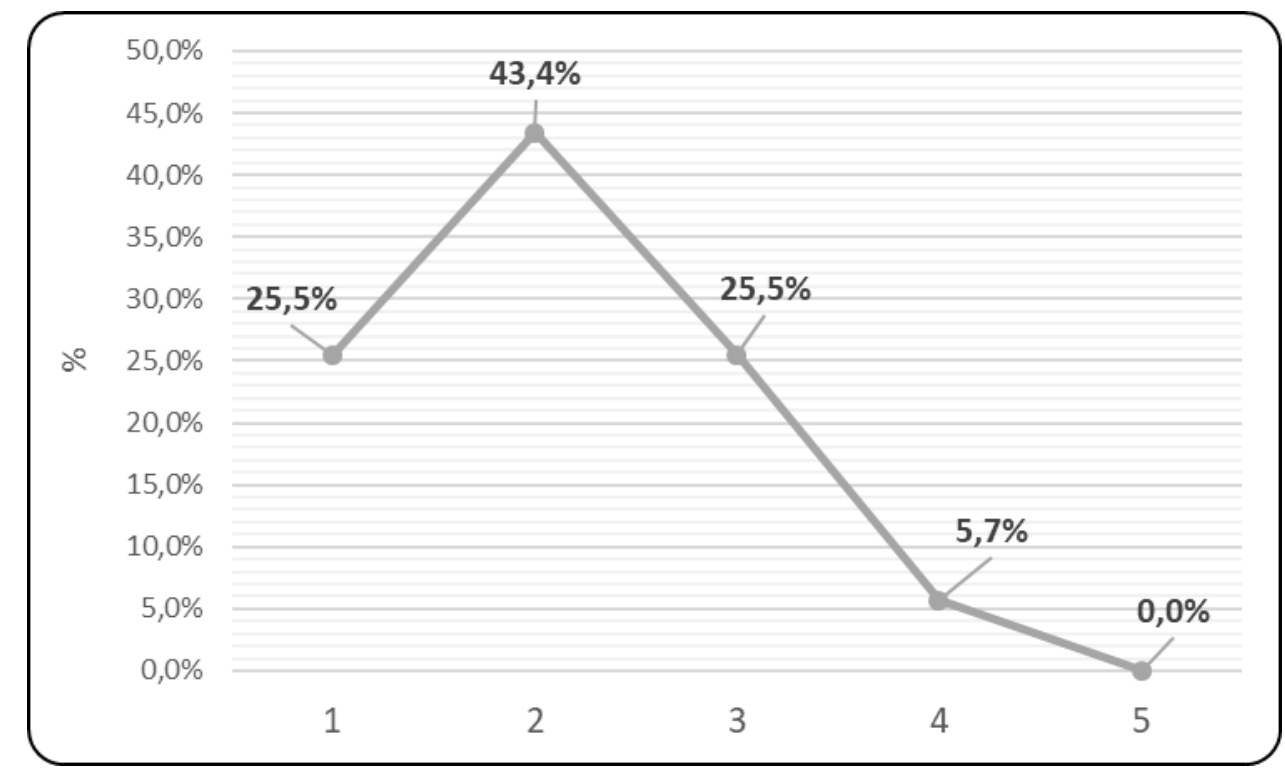

*1-es egyáltalán nincs tisztában, 5-ös teljes mértékben-tisztában van

\section{A gyermekek fejlesz̨tésen való részuétele}

A válaszadó szülők gyermeki $48,5 \%$-a részt vesz valamilyen fejlesztésen és $51,5 \%$-a nem vesz részt fejlesztésen. A 7. ábra szemlélteti a fejlesztésre járó gyermekek arányának megoszlását.

\section{A válaszadók véleményei a korai fejlesztések hatásáról A korai fejlesztés befolyásolja a fejlódést}

A válaszadó szakemberek többsége 71,7\%-a szerint a korai fejlesztés befolyásolja a gyermekeknél a pozitív irányba haladó fejlődést, 18,9\%-a szerint jellemző, 9,4\%-a igen befolyásolja, 0\%-a szerint kevésbé jellemző, illetve $0 \%$-a szerint egyáltalán nem jellemző. A válaszadó szülők tekintetében 76,7\%-a szerint a korai fejlesztés befolyásolja a gyermekeknél

a pozitív irányba haladó fejlődést, 19,4\%-a szerint jellemző, 0\%-a szerint igen befolyásolja, 2,9\%-a szerint kevésbé jellemző, illetve 1\%-a szerint egyáltalán nem jellemző (8. ábra). 


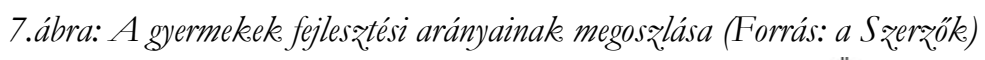

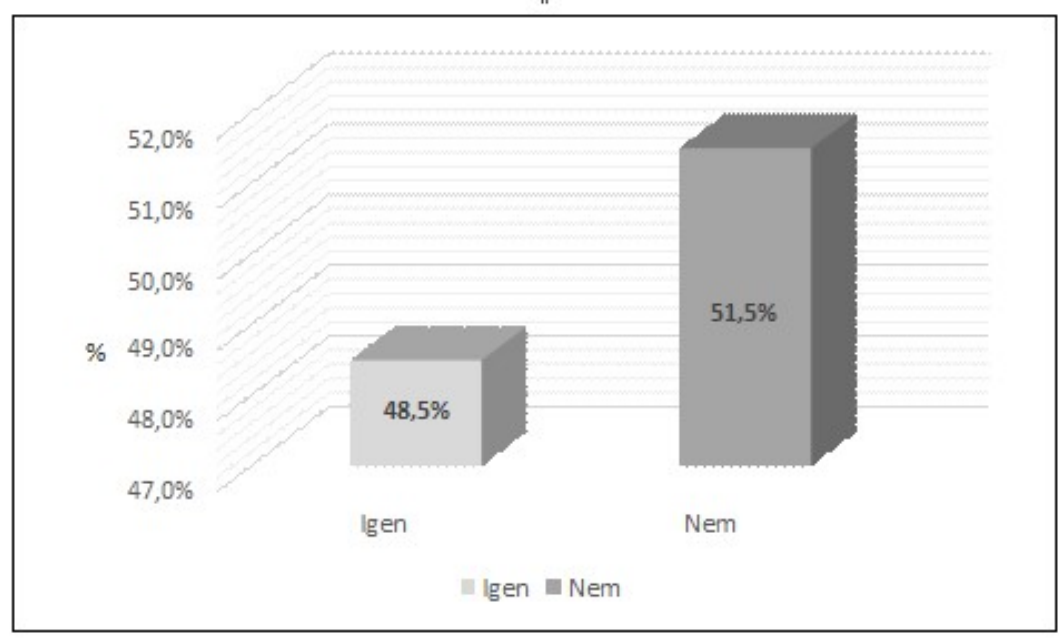

8. ábra: A szakemberek véleményének megoszlása a korai fejlesztés jótékony hatásáról (Forrás: a Szurzöke)

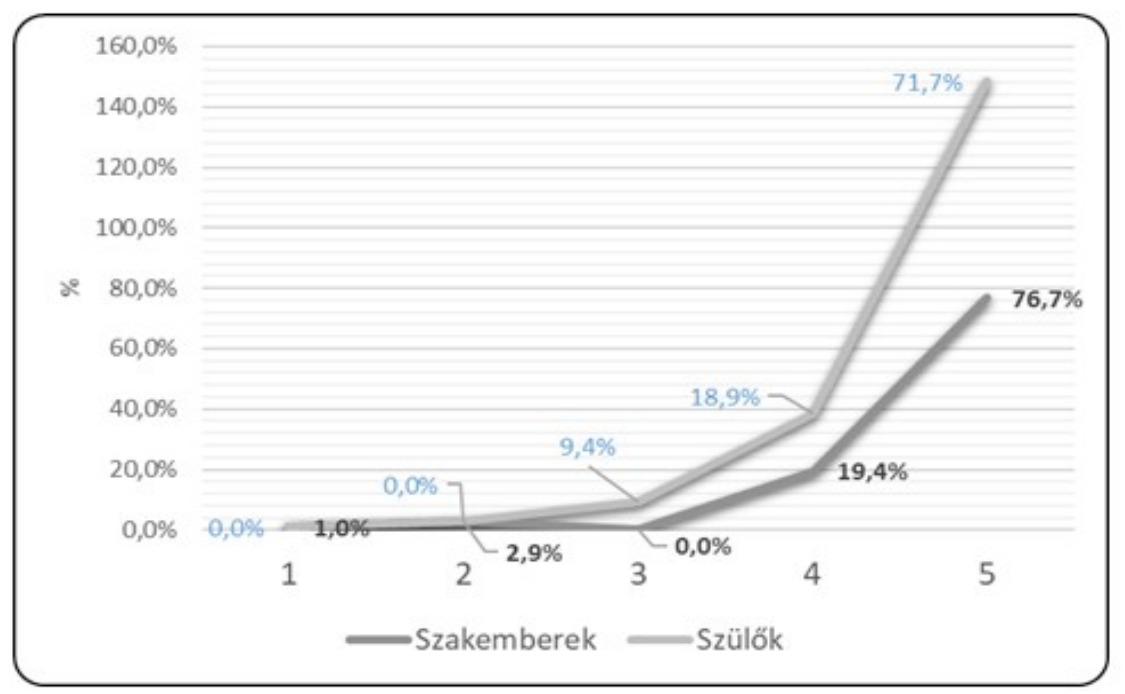

\section{A válaszadó szakemberek véleményei a fejlesztésekröl}

A válaszadó szakemberek tapasztalatait Likertskála alkalmazásával elemeztük az alapján, hogy a szülők a gyermekükkel való korai fejlesztésen való részvételt...

...jó lehetőségnek tartják-e?

A szakemberek szerint a szülők 18,5\%-a egyáltalán nem tartja jó lehetôségnek, 27,4\%-a talán jótalán nem jó lehetőségnek tartják, 13,2\%-a nem tartja jó lehetőségnek, 27,4\%-a igen jó lehetőségnek tartja, 17,9\%-a teljes mértékben jó lehetőségnek tartják a korai fejlesztést.

...beletörődéssel fogadták-e?

A szakemberek szerint a szülők 12,3\%-a egyáltalán nem törődnek bele, 33,0\%-a talán beletörődnek, 30,2\%-a nem törődnek bele, 
22,6\%-a igen beletörődnek, $1,9 \%$-a teljes mértékben beletörődött.

...stigmaként élik-e meg?

A szakemberek szerint a szülók 3,8\%-a egyáltalán nem stigmaként élik meg, 23,6\%-a szerint talán stigmaként élik meg, 18,9\%-a nem stigmaként éli meg, 34,9\%-a stigmaként élik meg, 18,9\%-a teljes mértékben stigmaként élik meg.

A gyermekük fejlődésének érdekében mindent megtesznek-e?
A szakemberek szerint a szülók 7,5\%-a egyáltalán nem tesznek meg mindent a gyermekük fejlődésének érdekében, 24,5\%-a talán mindent megtesznek, 27,4\%-a nem tesz meg mindent, 29,2\%-a igen mindent megtesz a gyermekének a fejlődése érdekében, 11,3\%-a teljes mértékben mindent megtesznek a gyermekük fejlődése érdekében.

A 9. ábra szemlélteti a szakemberek tapasztalásait arról, hogy szülőket hogyan érinti, ha a gyermekükkel a korai fejlesztésre kell járni.

9. ábra: A szakemberek tapasżtalati szerinti megoszlása (Forrás: a Szzrző́k)

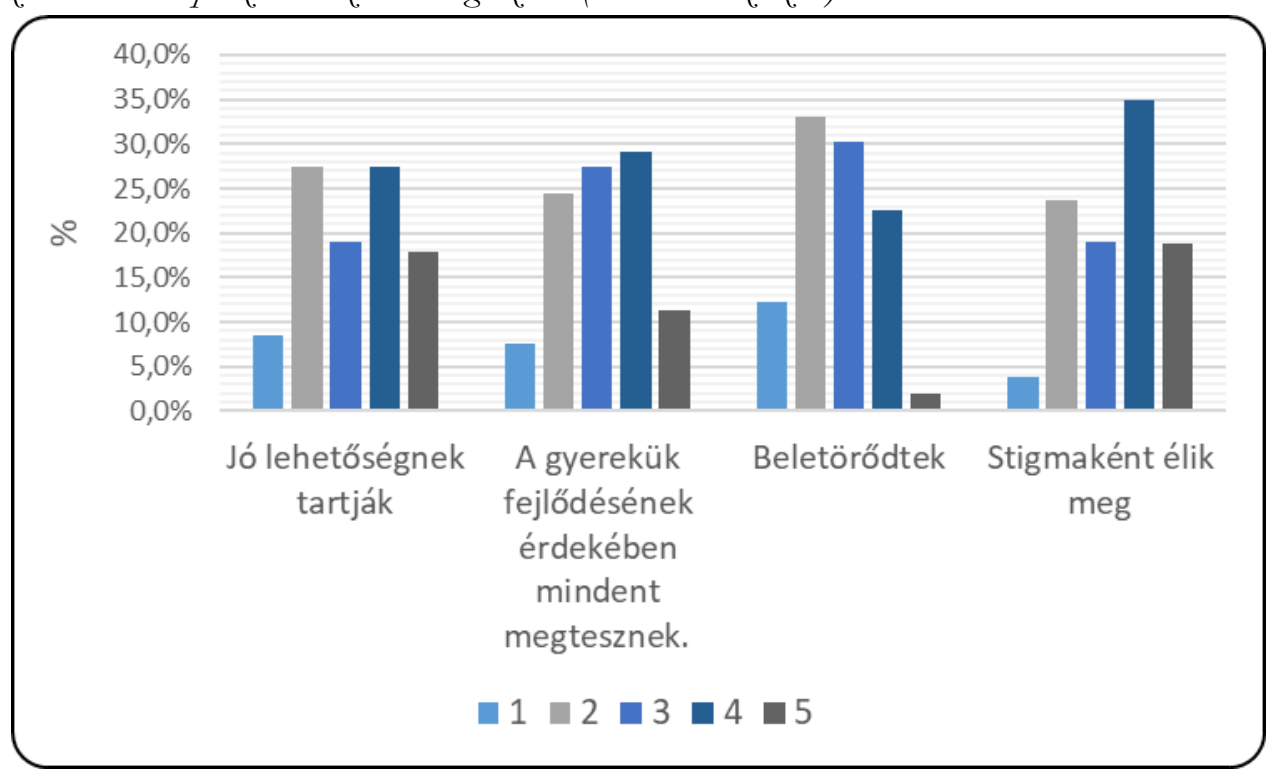

*1-es egyáltalán nem jellemző, 5-ös teljes mértékben jellemző

A válaszadók véleménye a rendszeres szürớvi zsgálatok fontosságáról

A válaszadók véleménye szerint a szülők 61,2\%-a szerint igen jó lenne-e a rendszeres szűrôvizsgálat, 35\%-a szerint teljes mértékben jó lenne, 3,9\%-a néha és $0 \%$-a szerint nem lenne jó.
A válaszadó szakemberek 51,9\%-a szerint igen jó lenne a rendszeres szûrővizsgálat, 41,5\%-a teljes mértékben jó lenne, 4,7\%-a vélekedik úgy, hogy néha és 1,9\%-a szerint nem lenne jó. A 15. sz. ábra szemlélteti a válaszadók véleményét a 0-6 éves korú gyermekek számára a rendszeres szúrővizsgálatok lehetőségét (10. ábra). 


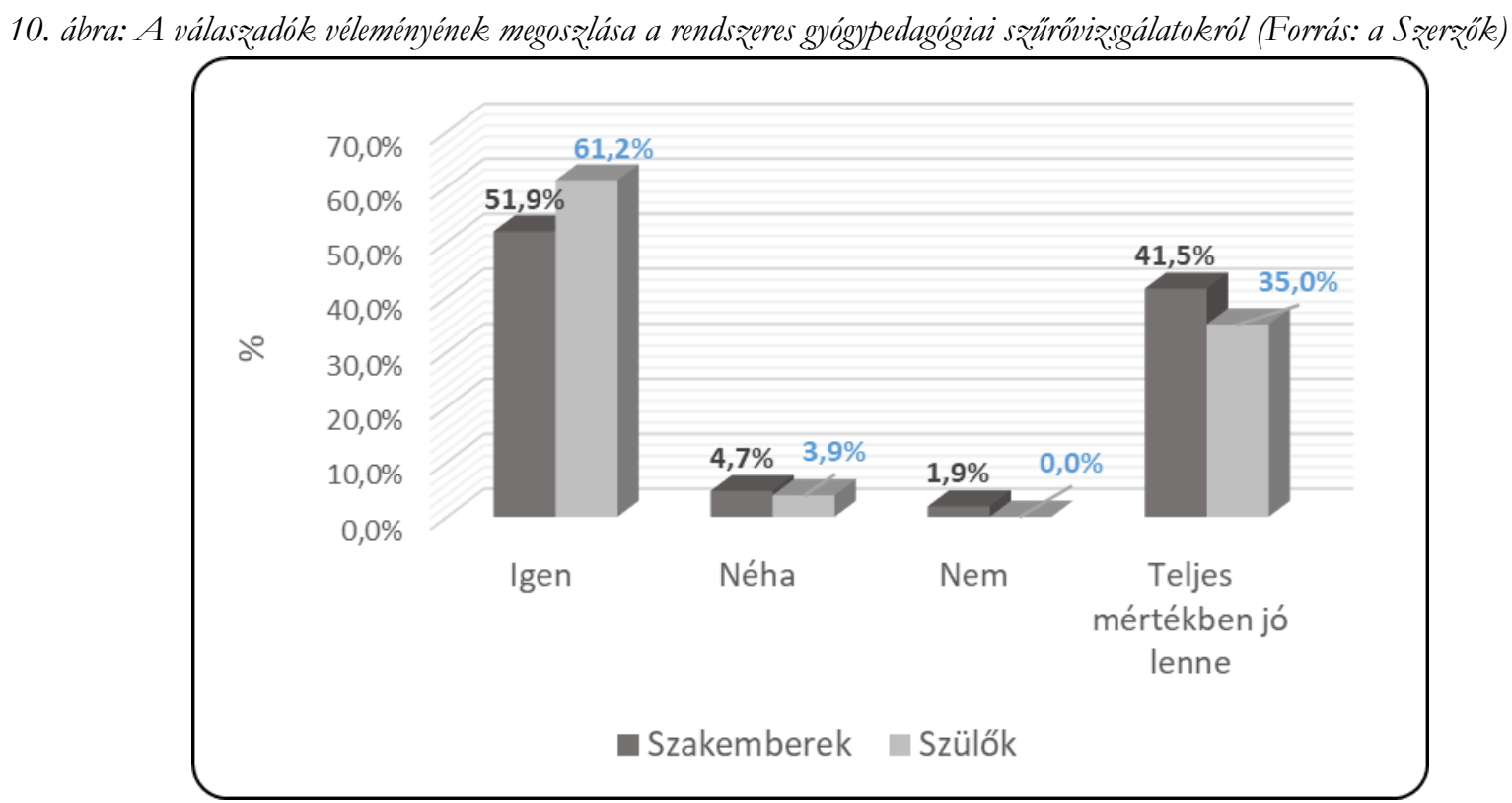

\section{A válaszadók véleménye az integrációról/ inklúzióról}

A válaszadók közül a szakemberek többsége 59,4\%-a úgy gondolja, hogy teljes mértékben befolyásolja a sikeres integráció/inklúzió a gyermekek jövőjét, 28,3\%-a igen befolyásolja, 6,6\%-a szerint talán, 4,8\%-a nem befolyásolja a sikeres integráció/inklúzió a gyermekek jövőjét és 0,9\%-a szerint egyáltalán nem.

A szülők $67,0 \%$-a szerint teljes mértékben befolyásolja, 21,4\%-a szerint igen befolyásolja, 6,8\%-a szerint egyáltalán nem és 4,9\%-a válaszolta, hogy talán befolyásolja. A 11. ábra szemlélteti a szülők és a szakemberek véleményét az integráció/inklúzió sikeres befogadásának hatásáról.

A válaszadók véleménye az intézményes és intézményen kivüli integrálásról

A szakemberek válaszaiból érzékelhető egy kis bizonytalanság, miszerint az intézményben megvalósuló integráció mind az óvodában, mind az iskolában nagyobb \%-ban a „néha” lenne jó ha az ép gyermekekkel jár egy csoportba egy fogyatékossággal élő gyermek. Az óvodában 36,8\%-a, iskolában 35,8\%-a gondolja így. A teljes mértékben helyesnek tartják óvodába 33\%-a, iskolába 26,4\%-a gondolja, 22,6\% talán igen és az iskolában 25,5\%-a érzi, hogy talán. Az óvodában4,7\%-a nem, 2,8\%-a talán nem. Az iskolában 5,7\%-a nem és 6,6\%-a talán nem lenne jó. A játszótéren való együtt játszás nagy többsége 79,2\%-a teljes mértékben helyesnek tartja. 11,3\%-a néha, 8,5\%-a talán igen, 0,9\%-a talán nem és $0 \%$-a, aki szerint nem lenne jó, ha egy ép gyermekkel együtt játszik egy fogyatékossággal élő gyermekkel.

A válaszadó szülők véleménye szerint az óvodában 43,7\%-a szerint teljes mértékben jó ha együtt vannak, 19,4\%-a néha, 25,2\%-a talán igen, 6,8\%-a egyáltalán nem, 4,95-a talán nem.

Az iskolában 37,9\%-a teljes mértékben, 19,4\%-a néha, 30,1\%-a talán igen, 6,8\%-a egyáltalán nem, 5,8\%-a talán nem. A játszótéren $67 \%$-a teljes mértékben, 17,5\%-a néha, 14,6\%-a talán igen, 1\%-a talán nem és $0 \%$-a gondolja úgy, hogy nem tartja 
helyesnek. A 2. táblázat szemlélteti a szülők és a szakemberek megoszlását az integráció elfogadásáról.

Viszont, arra a kérdésre, hogy egy SNI gyermeknek integrált intézményben vagy szegregáltan lenne jobb a nevelése 59,4\%-a választotta az integrált intézményi nevelést és 32,1\%-a a szegregált nevelést tartotta jónak, 8,5\%-a nem válaszolt. Ez arra enged következtetni, hogy nem minden esetben fogadnák be az SNI gyermeket

11. ábra: A sikeres integráció/inklúzió megoszlása a szülók és szakemberek körében (Forrás: a Sžrrö́k) (1-es egyáltalán nem befolyásolja, 5-ös teljes mértékeben befolyásolja)

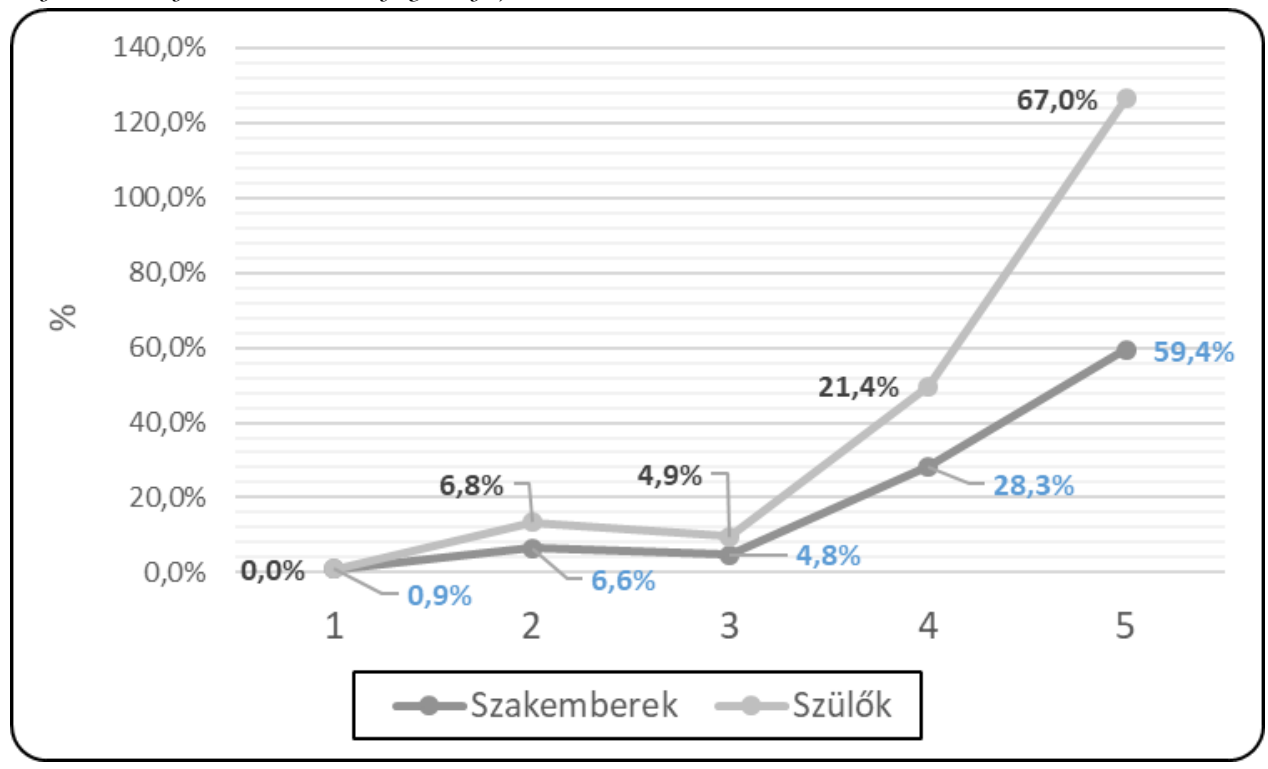

2. táblázat: A válaszadók véleményének megoszlása az integrációról (Forrás: a Sžrzộk) (1-es egyáltalán nem helyes, 5 ös teljes mértékeben helyes)

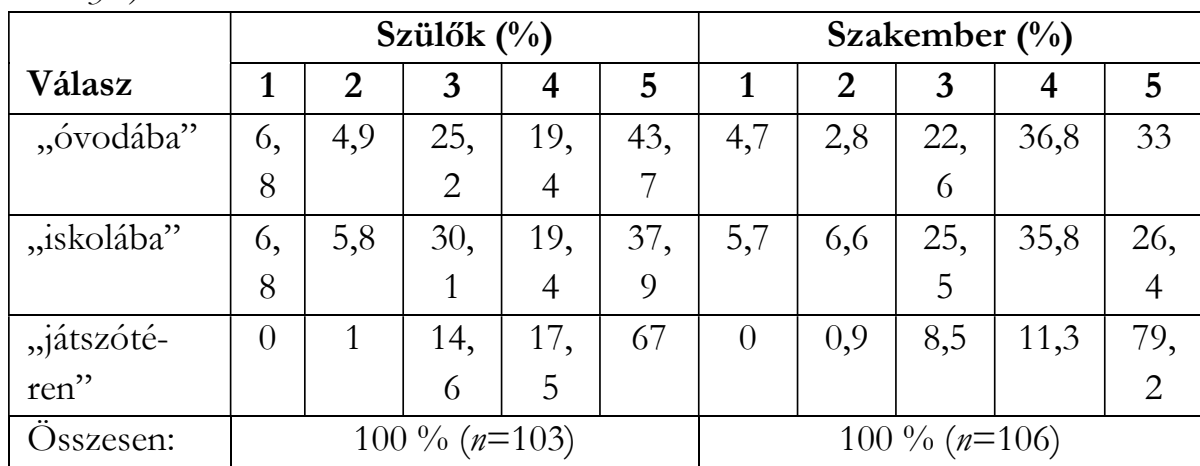




\section{Konklúziók}

Napjainkban sok gyermek nem a megfelelő ütemben fejlődik, ami később valamilyen nehézségeket okozhat a gyermek számára. A tanulmányunkkal szeretnénk felhívni a figyelmet a korai intervenció fontosságára a rendszeres gyógypedagógiai szűrővizsgálatok bevezetésének lehetőségére. Véleményünk szerint, ha lenne rendszeresen gyógypedagógiai szűrővizsgálat a gyermekek fejlődésének eredményei is jelentősen javulnának. A kérdőíves kutatásban mind a szülők 89\%-a, mind a szakemberek 93,4\%-a jó lehetőségnek tartaná a rendszeres szűrővizsgálatokat. A kérdőív segítségével szeretnénk feltárni, hogy mennyire informáltak a szülők, az óvodapedagógusok és a szakemberek a sajátos nevelési igényú gyermekek integrációjával és a fejlesztésekkel kapcsolatosan, illetve a szülők és a szakemberek elfogadják és támogatják-e a sajátos nevelési igényű gyermekek integrációját. A válaszadó szülők 67\%-a válaszolta, hogy teljes mértékben és 21,4\%-a igennel válaszolt, összesen 88,4\%-a vélekedik úgy, hogy befolyásolja egy SNI gyermek fejlődését az integrálás. 11,6\%-a gondolja úgy, hogy nem vagy talán. A válaszadó szakemberek közül a többsége 59,4\%-a úgy gondolja, hogy teljes mértékben befolyásolja a sikeres integráció/inklúzió a gyermekek jövőjét, 28,3\%-a igen befolyásolja, 6,6\%-a szerint talán, 4,8\%-a nem befolyásolja a sikeres integráció/inklúzió a gyermekek jövőjét és 0,9\%-a szerint egyáltalán nem.

A válaszadók óvodában 43,7\%-a, az iskolában 37,9\%-a, a játszótéren 67\%-a teljes mértékben elfogadja az ép gyermekével együtt jár sajátos nevelési igényú gyermek is. „Talán igen” válasszal is éltek a szülők, az óvodában 25,2\%-a, iskolában 30,1\%-a és a játszótéren 14,6\%-a fogadja el. Összesítve nagyobb \%-ban fogadják el a szülők a SNI gyermek integrálását. A kérdőíves kutatás szerint a válaszadó szakemberek bizonytalanok, nagy többsége a „néha” választ jelölték be az óvodai, iskolai integrálás kérdésénél, illetve arra a kérdésre, hogy egy SNI gyermeknek integrált intézményben vagy szegregáltan lenne jobb a nevelése 59,4\%-a választotta az integrált intézményi nevelést és 32,1\%-a a szegregált nevelést tartotta jónak, 8,5\%-a nem válaszolt. Ez arra enged következtetni, hogy nem minden esetben fogadnák be az SNI gyermeket.

A megkérdezett szakemberek többség 80\%-a tisztában van a korai fejlesztés igénybevételének módjával, de sajnos a $20 \%$-a viszont nincs tisztában. A kutatás során a szülók többsége $64,1 \%$-a kap tájékoztatást a gyermeke fejlődési szakaszairól. Az integráció/inklúzió, azt az elvet vallja, hogy speciális problémái miatt senki ne legyen megkülönböztetve, kirekesztve. Napjainkban a pedagógiai munka egyik kihívása az integráció/inklúzió sikeres megvalósítása (Czibere, 2006). Az óvodában megvalósuló integráció a kérdôiv alapján a szülôk nagy része teljes mértékben 43,7\%-a befogadja a fogyatékossággal élő gyermeket, az óvodapedagógusokkal ellentétben ők csak $33 \%$-uk, viszont 36\%-a választotta a „néha” válaszadás lehetőségét. Az iskolába történő integrálásról is hasonló a véleményük a szülőknek és a szakembereknek egyaránt. A kérdőíves kutatás bizonyítja, hogy a szakemberek 84,9\%-a érdeklődéssel lenének a továbbképzésekkel kapcsolatosan.

A korai intervenció fontossága beigazolódott az attitúd vizsgálattal, a válaszadó szakemberek 71,7\%-a teljes mértékben befolyásolja a gyermekek fejlődését a korai fejlesztés, 18,9\%-a jellemző és $8,5 \%$-a igennel válaszolt. A válaszadó szülők $76,7 \%$-a szerint teljes mértékben befolyásolja, 19,4\%-a igen, 2,9\%-a nem és 1\%-a érzi úgy hogy egyáltalán nem befolyásolja. A szülők és a szakemberek nagy többsége pozitívan vélekedik a koragyermekkori intervencióról.

A publikáció elkészitését a „GINOP-2.3.2-15-201600062 Életminöség fejlesztése Kelet-Magyarországon: Táplálkozás-, teljesitménybiológiai és biotechnológiai experimentális kutatások és eszlközfejlesztések a humán megbetegedések megelo"zésére és kezelésére" projekt támogatta. 


\section{Irodalom}

Ákoshegyi I.-né (1986): Szeleszárd város alsó tagozatos tanulöinak motoros teljesitménye és szociálökonómiai státusza közötti összefüggés viæsgálata. TF doktori értekezés, Budapest.

Andrásné, Teleki J. (2010): Az óvodások szomatikus prevenciója, az ortopédiai elváltozások - hanyagtartás, tartáshibák, deformitások - korrekciója. In: Bajomi, É.; Gaál, S-né; Andrásné, Teleki J.; Farmosi, I.; Gaál, S-né (szerk.) Mozgásfejlódés és fejlesztés az óvodában. Szarvas Press, Szarvas. 288-303.

Bakonyi F. \& Nádori L. (1979): Adatok a 4-12 évesek mozgáskoordinációjának életkori szintjeibez: Tanulmányok a TFKI kutatásaiból (1977-1978). Bp. 25-63.

Budai I. (szerk)(1996): Szociális munka az iskolában. Válogatás iskola szociális szakemberek, szociális és pedagógusképzésben résztvevők számára. Nemzeti Tankönyvkiadó, Budapest.

Czeizel B. (2009): A koragyermekkori intervenció múltja, jelene és remélt jövője. Gyógypedagógiai Szemle, 37.2-3.sz. 153-160.

Csirkés, Zs., Ramocsa, G., Földi, R., Bretz, K \& Hamar, P. (2015): Az Ayres-féle terápián alapuló mozgásfejlesztés biológiai rizikófaktorral született óvodások körében. In: Borbély, A.; Hamar, P.; Kotányi, M. (szerk.): Szines sporttudomány : Tanulmányok a 45. Mozgásbiológiai Konferencia előadásaiból. az Debrecen, Magyarország. Debreceni Campus Nonprofit Közhasznú Kft. 248-258.

Eigner B. (2012): Az anyai játékosság, mint védő faktor a korai kapcsolat alakulásában. In: Eigner B. (2012): A kora gyermekekori intervenció lehetöségei szülletéstöl három éves korig. Budapest, Magyarország.

Farmosi I. \& Gaál S.-né (2001): Óvodások testi fejlettsége, fizikai teljesítménye és motorikus struktúrája. In: Bejek G., Gombocz J. \& Krasovec F. (szerk.) Kalokagatbia. XXXIX: évf. 1-2. 36-63.
Farmosi I. (1999): Mozgásfejlódés. Dialóg Campus Kiadó. Bp.-Pécs. 14-42.

Farmosi, I. \& Gaál, S-né (2007): Óvodások és kisiskolások testi és mozgásfejlódése. Dialóg Campus Kiadó, Pécs.

Jenei T. (2012): Hátrányos helyzetú gyerekek korai fejlesztését segítő programok. Magyarországon Egy jó gyakorlat: a Biztos Kezdet program. In: Brezsnyánszky L., Gy-né, Harsányi J; Jenei, T. (szerk.) (2012): Tanulmányok a kora gyermekkor pedagógiája, pszichológiája köréböl. Bessenyei Könyvkiadó. Nyíregyháza 154-161.,

Kereki J. \& Lannert J. (2009): A korai intervenciós intézményrendszer hazai múködése kutatási zárójelentés. Zárótanulmány. web: http://www.fszk.hu/opi/szolgáltatás/ koraiintervenció/zárótanulmány pdf. Letöltés:2020.04.13. 10:10

Kereki J. \& Szvatkó A. (2015): A koragyermekkori intervenció, valamint a gyógypedagógiai tanácsadás, korai fejlesztés, oktatás és gondozás szakeszolgálati protokollja. Budapest, Magyarország: Education Társadalmi Szolgáltató Nonprofit Kft.

Kereki J. (2010): A koragyermekkori intervenció rendszerének anomáliái és jó gyakorlata. Gyógypedagógiai Szemle, 38. 1. 32-45.

Kereki J. (2013): A koragyermekkori intervenciós rendszer működésének legfontosabb problématerületei és fejlesztési lehetőségei. Gyógypedagógiai S zemle, 41.1. 23-38.

Kereki J.(2017): Utak. ELTE Bárczi Gusztáv Gyógypedagógiai Kar, Bp.

Kiss, E. (2019): Látássérült kisgyermekek kora gyermekkori intervenciója. Gyógypedagógiai tanácsadása, korai fejlesztése, óvodai nevelése. In: Meszéna, T-né (szerk.): Kaleidosžkóp : Rendszerszemléletben a kora terápiás háromszög. Budapest, Magyarország. Családbarát Ország Nonprofit Közhasznú Kft. 147-191.

Laoues N. (2017): A család és az oktatási intézmény szerepe a fogyatékkal élő gyermekek fejlődésében. In: Vargáné Nagy Anikó (szerk.): 
Családi nevelés 2. Debrecen: Didakt Kft., 19-49.

Márkus L. V., Fülöp K. Á. (2017): Kapcsolati szemléletű korai prevenció megvalósulása a bölcsődei és óvodai ellátás intézményeiben. In: Hámori E. (szerk.): "Team Around the Child". Gyakorlati modellek és tapasztalatok a kora gyermekkori intervenció és prevenció területéről. Budapest, Magyarország: Humanitás Szociális Alapítvány. 119-141.

Mező K., Mező F., Kelemen L. (2015). Az együttnevelés elmélete és gyakorlata, In Szilágyi B., Mező K., \& Mező F. (szerk.): Az együttnevelés útjai, Debreceni Egy. K., Debrecen. 7-22.
Mercsné Konyári A.(2019): Attitüdvizsgálat és esettanulmány az integráció tükrében. Debreceni Egyetem, Gyermeknevelési és Gyógypedagógiai Kar. Hajdúböszörmény.

Mészáros J., Farmosi I., Frenkl R. \& Mohácsi I. (1990): A gyermeksport biológiai alapjai. Sport, Bp.

Rosta K. (2006): Add a kezed! A mentális fejlódés segitése sajátos nevelési igényü gyermekeknél. Logopédia Kiadó, Budapest.

Völgyesi P. (1993): Életkorok Pszichológiája. GATE jegyzet, Gödöllő.13-15. 